\title{
The Key to Success: \\ The Role of Local Government in the Organization of Smallpox Vaccination in Sweden
}

\author{
PETER SKÖLD*
}

Two different preventive measures were used against smallpox before this disease was finally eradicated from the world in the 1970s. Inoculation-which was based on folk medicine experiences-was brought to Europe and North America in the early eighteenth century. This method aimed to give immunity to smallpox by putting matter from a smallpox pustule into the arm of a susceptible child, thereby causing a mild infection. At the beginning of the nineteenth century, vaccination was employed throughout the world. The difference between inoculation and vaccination was that the latter used matter from cowpox, which did not involve any risk of causing natural smallpox. There were, however, other dissimilarities between the two methods. In this study, the organization of these preventive activities will be compared. The crucial question is why inoculation faced great problems in Sweden, while vaccination was immediately very successful. In its high vaccination rates, Sweden also differed from many other countries, where the method met with resistance or faced problems of organization. Many of the differences between the organization of inoculation and vaccination in Sweden also explain why its vaccination rates differed from those of other countries during the first half of the nineteenth century. The key elements were the local administration and the role of the clergy and their assistants. ${ }^{1}$

The role of the clergy within the medical system dominated medical discussion from $1810{ }^{2}$ this discussion originated with a proposal which Dr Carl Trafvenfeldt, a member of the Medical Board, sent to Parliament in 1809 . He suggested that theological and medical education should be brought closer together and that theological students should learn some medicine so they could provide a basic service in their parishes, ${ }^{3}$ and in this way the countryside would receive better health care. In the absence of a sufficient number of physicians, the church

\footnotetext{
* Peter Sköld, Associate Professor, The Demographic Database, Umeå University, Sweden.

${ }^{1}$ The importance of the clergy has already been stressed by $\mathrm{R}$ Norrman, 'Prästerna och vaccinationen. En regional undersökning avseende Uppsala län 1811-1820', Kyrkohistorisk Arsskrift, 1979, 80: 100-31, on p. 122.

${ }^{2}$ For a detailed compilation of instructions, letters and texts involved in the discussion, see
}

\begin{abstract}
Handlingar angående medicinska kunskapers inhämtande af blifvande prester, för att dermed kunna gå Församlingarnes innevånare tillhanda, Stockholm, 1816. The compilation is signed $\mathbf{H}$. It was probably made by Sven Hedin, Royal Physician and member of the Medical Board.

${ }^{3} \mathrm{R} \AA$ Gustafsson, Traditionernas ok. Den svenska hälso- och sjukvårdens organisering $i$ historie-sociologiskt perspektiv, Falköping, Esselte Studium, 1987, pp. 246-9.
\end{abstract}




\section{Peter Sköld}

provided a useful organizational base. Trafvenfeldt's plan met with considerable criticism, from both physicians and clergy. The district physician of Uppsala, Dr Afzelius, totally rejected it, while most clergy were concerned about whether it would be possible to control the system at parish level in order to gain the confidence of the public. ${ }^{4}$

In 1812 Major C G Stjernswärd published a plan for reorganizing health care in Sweden, in which he suggested that church assistants should be replaced by parish physicians. ${ }^{5} \mathrm{He}$ was critical of both physicians and clergy. ${ }^{6}$ Another publication considered it foolish for anyone other than physicians to be involved. ${ }^{7}$ Nevertheless, some of the physicians questioned considered that church assistants could be used to advantage because they had contact with the public and could serve the community by practising medicine. Occasionally, older physicians even applied for these jobs. ${ }^{8}$ The plans to involve the clergy in medical practice included some grants for which theological students could apply. The number of these was reduced in 1824, and they were withdrawn in 1841. Rolf Gustafsson concludes that the main reason why clerical medicine never became important was the lack of organizational changes and a sceptical clergy. ${ }^{9}$ In 1843 , the responsibility for local health care was transferred from the church to the local authorities. ${ }^{10}$ Nevertheless, the clergy maintained a key position in the organization of vaccination in Sweden.

Johan Söderberg claims that the relatively low vaccination rates in country districts were related to a strong religious influence and a fatalistic attitude. ${ }^{11}$ The relation between vaccination and a set of variables including the clergy and their assistants will be evaluated in this study.

\section{Inoculation, 1754-1801}

In the 1720s inoculation was introduced in England. ${ }^{12}$ By inoculating a patient with smallpox lymph a slight infection gave life-long immunization. Alex Mercer

\footnotetext{
${ }^{4}$ A Björverud, 'Prästmedicinen. Debatten i Sverige i början på 1800-talet', Sydsvenska Medicinhistoriska Sällskapets Arsskrift, 1990, 20: 219-38. Något om Prest-medicin. Hämtadt ur en Dansk Journal (signed S.P.L.), Uppsala, 1810.

${ }^{5}$ In each church the pastor had one or two assistants. One was responsible for the music, and the other was called the klockare (church bell ringer), who would assist in practical matters, and it was the latter who were mostly involved with vaccination. $\mathrm{H}$ Wentz, Klockaren $i$ helg och söcken, Lund, Ekstrand, 1980, pp. 163-65.

${ }^{6} \mathrm{C}$ G Stjernswärd, Oförgripelige tankar, om medel, till winnande af en mera allmän och förbättrad sjukvård, $i$ synnerhet $i$ rikets conquettereade provincer, utan statens och allmänhetens betungande, Christianstad, 1812.

${ }^{7}$ Behörig granskning af de så kallade, oförgripliga tankar, hwilka herr majoren och riddaren C. G. Stjernswärd innewarande år från
}

trycket utgifwit, om medel, till winnande af en mera allmän och förbättrad sjukvård, $i$ synnerhet $i$ rikets conquettereade provincer, utan statens och allmänhetens betungande, Örebro, 1812.

${ }^{8}$ Wentz, op. cit., note 5 above, pp. 163-5.

${ }^{9}$ Gustafsson, op. cit., note 3 above, pp. 246-9.

${ }^{10} \mathrm{~J}$ Rogers, 'Hälsovårdsutvecklingen i Sverige under den epidemiologiska transitionen. En jämförelse med England och Tyskland', Sydsvenska Medicin-historiska Sällskapets Årsskrift, 1990, 20: 103-17, on p. 106.

${ }^{11} \mathbf{J}$ Söderberg, Civilisering, marknad och våld $i$ Sverige 1750-1870. En regional analys, Stockholm, Almqvist \& Wiksell International, 1993, pp. 154-8, 228-36, 244-6.

${ }^{12} \mathrm{G}$ Miller, The adoption of inoculation for smallpox in England and France, Philadelphia, University of Pennsylvania Press, 1957, pp. 70-90. 


\section{The Organization of Smallpox Vaccination in Sweden}

suggests "that the use of inoculation probably protected many from smallpox to an extent which could have brought reductions in the overall rate in the population". ${ }^{13}$ Inoculation was not introduced in Sweden until after 1750. In 1754, Dr David Schultz was sent to London to study the new method. When he returned two years later, the first operations were carried out at an orphanage in Stockholm. ${ }^{14}$

\section{National and Medical Authorities}

Since inoculation was considered to be dangerous, the Medical Board (Collegium Medicum) decided that only physicians should be permitted to make the incision. ${ }^{15}$ The Board received applications from lay people for permission to inoculate, but with a few exceptions it insisted that a physician must be present. ${ }^{16}$ This policy stemmed from a Royal letter of 1756 which stated that "no inoculation may be made, without an experienced medical doctor being present". ${ }^{17}$ Here we have one of the most important obstacles to the adoption of inoculation in Sweden: the policy of the state. The Royal Office (Kungl. Maj:t) supported inoculation, but was at the same time anxious not to cause any damage. So the practice was made too restricted and regulated. The Medical Board considered it beyond its power to give permission to inoculate to everyone who asked. The Royal Instruction to the Medical Board in 1797, stated: "Likewise the Medical Board seeks to promote public confidence in inoculation by ensuring the necessary precautions are taken and that the operation is not performed by unskilled persons, as the disease could spread among those not properly inoculated". ${ }^{18}$

The Royal Office never gave permission for uncontrolled inoculation, and the Medical Board was too busy dealing with the problems of inoculation in Stockholm, to construct a network by which different parts of the Swedish administrative structure could co-operate to promote the practice.

\footnotetext{
${ }^{13}$ A Mercer, Disease, mortality and population in transition: epidemiological-demographic change in England since the eighteenth century as part of a global phenomenon, Leicester University Press, 1990 , p. 72.

${ }^{14}$ Provincial doctorernes til Kongl. Medical Board inlemnade Berättelser, rörande deras ämbets förrättningar, desse senare åren, $i$ synnerhet sedan siste Riksdag, Stockholm, Lars Salvius, 1761, pp. 84-6.

${ }^{15}$ Royal letter to Medical Board, 31 March 1756 (EIA6:17), Medicinalstyrelsens äldre arkiv (The Medical Board Archive), Riksarkivet (National Archives, Stockholm).
}

\footnotetext{
${ }^{16}$ Medical Board record, 16 March 1770 (A1A:23, 11:3), Medicinalstyrelsens äldre arkiv, Riksarkivet. This was an important step which led to the emphasis on the physician's persona in biomedical practice. K Finkler, 'Sacred healing and biomedicine compared', Med. Anthropol. $Q$., 1994, 8 (2): 178-97, pp. 187-8.

${ }^{17}$ Royal letter of 31 March 1756, signed Adolph Fredric (E1A:6, 16:77),

Medicinalstyrelsens äldre arkiv, Riksarkivet.

${ }^{18}$ Kongl. Maj:ts Förnyade Nådiga Instruction för dess Collegium Medicum. Gifwen Stockholms Slott den 28 october 1797, Stockholm, 1798.
} 


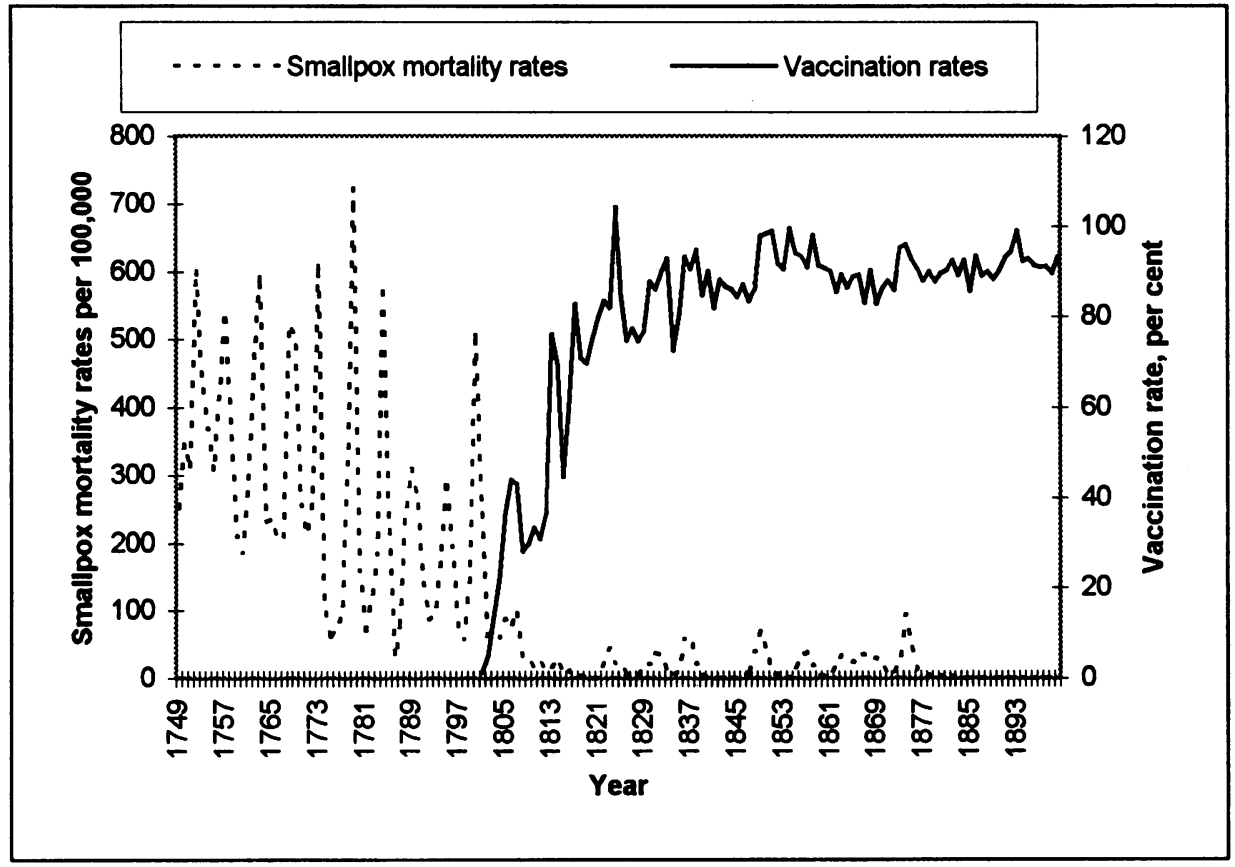

Figure 1: Smallpox death rates per 100,000 and vaccination rates (proportion of the number of born children during the previous year, infant mortality removed).

Sources: Bidrag till Sveriges officella statistik (BiSOS), serie K, 1860-1900. G Sundbärg, 'Döde efter kön, ålder och civilstånd i Sverige för åren 1751/1900 samt Medelfolkmängden efter kön och ålder under femårsperioderna för samma tid', Statistisk Tidskrift, 1905: 107-63. Compiled population records; Statistiska Centralbyråns arkiv (the older archive of the Tabellkommissionen); Riksarkivet, Stockholm.

\section{The Medical Profession}

The Health Commission ${ }^{19}$ (Sundhetskommissionen) and the physicians in Stockholm were immediately enthusiastic about the new method. Four of them began to inoculate at the Orphanage of the Masonic Order (Frimurarbarnhuset). In 1760, the first steps were taken towards the establishment of an inoculation house in Stockholm, ${ }^{20}$ and six years later the institution was opened. ${ }^{21}$

\footnotetext{
${ }^{19}$ The Collegium Medicum was founded in 1663 , and held the overall responsibility for health care in Sweden. In 1737 the

Sundhetskommissionen was established with a certain responsibility for the control of epidemic diseases. The practice of the latter was discontinued in 1766. I Flygare, 'Den centrala medicinalförvaltningen', in W Kock (ed.), Medicinalväsendet $i$ Sverige 1813-1962,
}

Stockholm, AB Nordiska Bokhandelns Förlag, 1963, pp. 7-101, on pp. 9-13.

${ }^{20}$ Kongl. Sundhets-Commissionens kundgörelse, angående et Koppympnings Hospitals Inrättande $i$ Stockholm, Stockholm, Lars Salvius, 1760.

${ }^{21} \mathrm{P}$ Sköld, The two faces of smallpox: $a$ disease and its prevention in eighteenth-and nineteenth-century Sweden, Umeå, Demographic Data Base, 1996, pp. 309-14. 


\section{The Organization of Smallpox Vaccination in Sweden}

The strategy was first to win acceptance among the rich, who would serve as good examples for the rest of the population. However, it soon turned out that physicians had great difficulty in attracting groups other than the upper classes and orphans to the establishment. ${ }^{22}$ There were several reasons for this. Many people were not sure if they could trust the physicians. The country's medical system had been established fairly recently and most people still relied on folk medicine to treat or prevent diseases. ${ }^{23}$ Moreover, there were only about 140 members of the medical profession in Sweden in the 1780s, which was an insufficient number to carry out inoculation and to visit people in their homes. ${ }^{24}$

If the cut in the arm was too deep or too much smallpox matter was put into it, the outcome could be severe and even fatal. There was also a risk that the inoculated person would infect others, who would then contract the disease via the respiratory system. In these cases, there would be no difference from regular smallpox infections. ${ }^{25}$ Nevertheless, the dangers of inoculation were more often imagined than real. Very few people actually died as a result of it. The reported large-scale inoculations in Sweden between 1756 and 1801 resulted in only eight deaths among 2,229 inoculated children, and no one ever proved that the method had actually started an epidemic. ${ }^{26}$ All the same, the physicians reported public mistrust grounded in the belief that the risks were great. ${ }^{27}$ It was rumoured, for example, that inoculated persons would not live longer than forty years ${ }^{28}$ and that inoculated children could still be infected by smallpox. ${ }^{29}$

About 300 children were inoculated at the Inoculation House (Koppympningshuset) in Stockholm between 1766 and 1780, much fewer than expected. The Medical Board had tried to convince the public with notices in the newspapers and proclamations in the churches. Dr Carl Ribben stated at a Board meeting in 1781 that he was sure that neither the rich nor the poor in Stockholm would send their children to the establishment any more. In the year before, only two children had been inoculated. The Inoculation House offered free inoculation, but the parents had to leave their children there for two or three weeks. According to Dr Ribben, this was out of the question for most people. ${ }^{30}$

\footnotetext{
${ }^{22}$ A Bäck, Introduction to Berättelser till riksens höglofl. ständer rörande medicinal werkets tillstånd $i$ riket, Stockholm, Lars Salvius, 1769, p. A 5 .

${ }^{23} \mathrm{P}$ J Bergius, 'Rön; om en koppo-smitta, som liknar ympning; jämte skäl til koppo-ympningens antagande här i riket, in Kongl. Vetenskaps Academiens Handlingar för år 1766, Stockholm, 1766, pp. $40-1$.

${ }^{24}$ Gustafsson, op. cit., note 3 above, p. 221.

${ }^{25} \mathrm{R}$ McGrew, Encyclopedia of medical history, London, Macmillan, 1985, p. 155.

${ }^{26}$ Sköld, op. cit., note 21 above, pp. $292-2$, 327-32.

${ }^{27} \mathrm{D}$ Schultz, 'Annual report to the Medical Board, 7 January, 1765', in Berättelser, inlämnade
}

til Kongl Medical Board, rörande medicinalwerkets tilstånd $i$ riket, Stockholm, Lars Salvius, 1765, pp. 8-22.

${ }_{28}^{28}$ Inrikes Tidningar, no. 15, 21 February 1765.

${ }^{29}$ Physicians often had to deny rumours like this. Two children inoculated by Peter Johan Bergius were later reported as having contracted smallpox but when the physician saw them it was apparent that it was chickenpox, not smallpox. $P$ J Bergius, 'Berättelse om koppympningen', in Berättelser, inlämnade til Kongl Medical Board, rörande medicinal-werkets tilstånd $i$ riket, Stockholm, Lars Salvius, 1765, pp. 258-60.

${ }^{30}$ Medical Board record, 26 February 1781 (AIA33:17(7)), Medicinalstyrelsens äldre arkiv Riksarkivet. 


\section{Peter Sköld}

However, it was not only the public who believed that inoculation involved certain risks. So too did physicians. We must understand their fear in the professional context. During the eighteenth century, the medical profession was not highly ranked in Swedish society, but it had begun to gain prestige. Therefore, most physicians were afraid of losing financial and social status. This meant that they took every precaution possible before performing the operation, including a preparation time of two weeks when the patients were put on a strict diet. Then the physician visited the patient daily during the two weeks following the inoculation, to observe the results. This made the operation expensive - an explanation often given by physicians as to why the practice was limited. ${ }^{31}$ Risse states that "In accordance with humoralism, physicians quickly transformed the rather simple folk method into a complex medical procedure". ${ }^{32}$

\section{Local Authorities and the Clergy}

The practice of inoculation was sanctioned by the Medical Board only when it involved physicians. The system of monopoly was one of the main impediments to the popularization of inoculation in Sweden.

Several clergymen certainly approved of the method, and had their children inoculated. But the church as an organization did not want to take an active part, with the accompanying responsibility. Inoculation was a medical matter, the clergy argued, and therefore a concern of the physicians. ${ }^{33}$ This attitude resurfaced again later when there was a great debate in Sweden in the early nineteenth century over whether medicine should form part of the education of the clergy. Most clergymen did not approve of the idea of becoming medical assistants, as this would interfere with their primary religious duties, but there were exceptions. When vaccination against smallpox was introduced, the clergy and their assistants were immediately involved, and their work was an important element in the success of this method. ${ }^{34}$

\section{Vaccination, 1801-1900}

The first initiatives to promote vaccination in Sweden and in the rest of Europe were taken independently of medical authorities and government. ${ }^{35}$ Nevertheless, effective vaccination could not be established, organized and run without the involvement of the state. Sweden was initially influenced in this matter by England,

\footnotetext{
${ }^{31}$ Sköld, op. cit., note 21 above, pp. 316-18.

${ }^{32} \mathrm{G}$ Risse, 'Medicine in the age of Enlightenment', in A Wear (ed.), Medicine in society: historical essays, Cambridge University Press, 1992, pp. 149-96, on p. 191.

${ }^{33} \mathrm{M}$ Larsson, Kroppens rationalisering. Folkhälsoupplysning under 1700-talets första hälft, Stockholm, Sociologiska institutionen vid Stockholms universitet, 1993, pp. 22-25.
}

\footnotetext{
${ }^{34} \mathrm{P}$ Sköld, 'From inoculation to vaccination: smallpox in Sweden in the eighteenth and nineteenth centuries', Popul. Stud., 1996, 50 (3): 247-62.

${ }^{35}$ For a comparative discussion of health care organization in Sweden, Germany and England, see Rogers, op. cit., note 10 above, pp. 103-17.
} 


\section{The Organization of Smallpox Vaccination in Sweden}

France, Prussia and Denmark. However, it was not long before these countries varied in how they each organized the practice of vaccination. ${ }^{36}$

The first vaccination in Sweden was carried out in October 1801 by Eberhard Zacharias Munk af Rosenschöld. Early the following year, Dr Gahn introduced the method in the two main orphanages in Stockholm. ${ }^{37}$ The most active physician during 1802 was Dr Trafvenfeldt, who vaccinated 144 persons at the Vaccination House (Vaccinationshuset) between January and October. ${ }^{38}$ At a meeting in May 1803, the Medical Board decided finally to abandon inoculation and replace it entirely with vaccination. ${ }^{39}$

By 1802 the monopoly system that had limited the right to vaccinate to physicians and surgeons only had been abandoned. The medical authorities realized that it would be impossible to vaccinate nation-wide without the assistance of laymen. In the instruction for church assistants in 1805 , it was stated that they should all be properly trained in the practice of vaccination. From this date onwards they dominated the registers of vaccinators, followed later by midwives. This meant that the medical organization could benefit from the church organization that had been built up 150 years earlier. The clergy kept records on every person in Sweden, from birth to death, they were also instructed to note vaccination in the records from information provided by local vaccinators. Their registers were sent to Stockholm, where the details were compiled at the Medical Board and published every year. If parents did not vaccinate their children, they were exhorted to do so both in church and at parish meetings.

Vaccination had been introduced into all European countries at the beginning of the nineteenth century. Organization, strategies and results varied. In some countries the state decided to force the implementation of vaccination by laws making it compulsory. In 1816 Sweden was one of the first to pass such a law, which was also one of the most restrictive..$^{40}$ This increased vaccination rates while smallpox mortality decreased.

${ }^{36}$ E P Hennock, 'Vaccination policy against smallpox, 1835-1914: a comparison of England with Prussia and Imperial Germany', Soc. Hist. Med., 1998, 11 (1): 49-72.

${ }^{37}$ Letter from the Medical Board to the Royal Office, Stockholm, 4 October 1802, Letters from the departments, nos. 2492 1802, Kungl. Maj:ts arkiv (Archive of the Royal Office), Riksarkivet.

${ }^{38}$ Vaccination report from Carl Trafvenfeldt, Stockholm, 25 October 1802 (E4:1),

Medicinalstyrelsens äldre arkiv, Riksarkivet. The Inoculation House was founded in 1766. When vaccination was introduced in 1801 , it kept its original name until 1805 when it was changed to 'The Inoculation and Vaccination House'. In 1816 the name was changed to 'The Vaccination

House'. For simplicity's sake I use the final form for references after 1801 .

${ }^{39}$ Medical Board record, 20 May 1803 (AIA: 55 (423-30:3)), Medicinalstyrelsens äldre arkiv, Riksarkivet.

\footnotetext{
${ }^{40}$ Compulsory vaccination was introduced into Bavaria in 1807, Denmark in 1810 and Norway in 1811. These laws in these countries did actually state indirect obligation. In Denmark, for example, people needed a vaccination certficate in order to get confirmed or married. The Swedish law had no such links, it simply stated that a fine was payable by those parents who had not vaccinated their children before the age of two years. J Stein, 'Die Pockenvakzination in Preussen bis zum Reichsimpfgesetz von 1874 unter besonderer Berücksichtigung des Regierungsbezirkes Frankfurt (Oder)', Zeitschrift für ärtzliche Fortbildung, 1987, 20: 1081-83; A Völker, 'Einige Markierungspunkte aus der Geschichte der Pockenschutzimpfung', Zeitschrift für die gesamte innere Medizin und ihre Grenzgebiete, 1990, 13: 392-96; O Malm, Kopper og Vaccinationen $i$ Norge, Kristiania, $\mathrm{H}$ Aschehoug, 1915, pp. 71-4; and P Thestrup, Vaccinations-kommissionen og
} 


\section{Peter Sköld}

While a majority of Swedish children were vaccinated, many infants died before this could be done, as the method was seldom performed during the first six months of life. There was no serious challenge to vaccination. A vote against the 1816 law was rejected in 1850; this was repeated six times during the nineteenth century. An organized opposition to vaccination was not seen until the turn of the twentieth century and the law was not abandoned until 1977, five years before the WHO declared smallpox eradicated from the globe. $^{41}$

\section{National and Medical Authorities}

The Royal Office had the final responsibility for vaccination. Under it, the Medical Board administered the programme. Vaccination appeared during a period of organizational change. In 1797, the Surgeons' Society (Kirurgiska Societeten) was incorporated into the Medical Board. This strengthened the central power over medicine and health care in Sweden. Several reforms of the health care system followed in the first years of the nineteenth century, and in 1813 the Medical Board was given the status of a civil service department, under the new name Sundhetskollegium. One member was appointed to be responsible for vaccination and the eradication of smallpox, and the Sundhetskollegium was to be consulted on every related question. ${ }^{42}$

Once the Medical Board had decided to support vaccination it needed the approval of the King to continue. In January the Board received a letter stating that King Gustaf IV Adolf supported vaccination and that he welcomed every effort to promote it. ${ }^{43}$ On 21 January 1802 a request that the Medical Fund should provide 500 riksdaler for this purpose was sent to the Royal Office. ${ }^{44}$ The

befolkningsstatistikken', in K Hjort (ed.), Spor-arkiver og historia, Copenhagen,

Rigsarkivet, GAD, 1987, pp. 339-61, on pp. 342-6.

${ }^{41}$ Sköld, op. cit. note 21 above, pp. 450-60.

${ }^{42}$ Gustafsson concludes "that the united department, firmly establishing medical leadership over Sweden's medical organization, appeared more than sixty years before modern breakthroughs in science". Gustafsson, op. cit., note 3 above, pp. 230-43. Letter from the Medical Board to the Royal Office, Stockholm, 25 May 1824, (48:331), Kungl. Maj:ts arkiv, Riksarkivet.

${ }^{43}$ Dr Carro of Vienna had vaccinated the Count de la Gardie's only son and had then been told that the Swedish King was a keen partisan of vaccination; "Le Comte a communiqué cette inoculation á Májesté, qui lui a ecrit unne lettre de felicitation \& d'approbation dávoir su profiter d'une decouvérte, jui promet dáusi grands avantages a l'humanité". C F Liljewalch, 'Bref til Kongl. Collegium Medicum angående en Utländsk Resa', Läkaren och Naturforskaren, Strängnäs, 1805, 14: 376.

${ }^{44}$ Letter from the Medical Board to the Royal Office, 21 January 1802, vol. 145, Kungl. Maj:ts arkiv, Riksarkivet. C Zetterström, Initia historiae vaccinationis in Svecia, Uppsala, Zeipel \& Palmblad, 1816-1821, pp. 98-9. 
The Organization of Smallpox Vaccination in Sweden

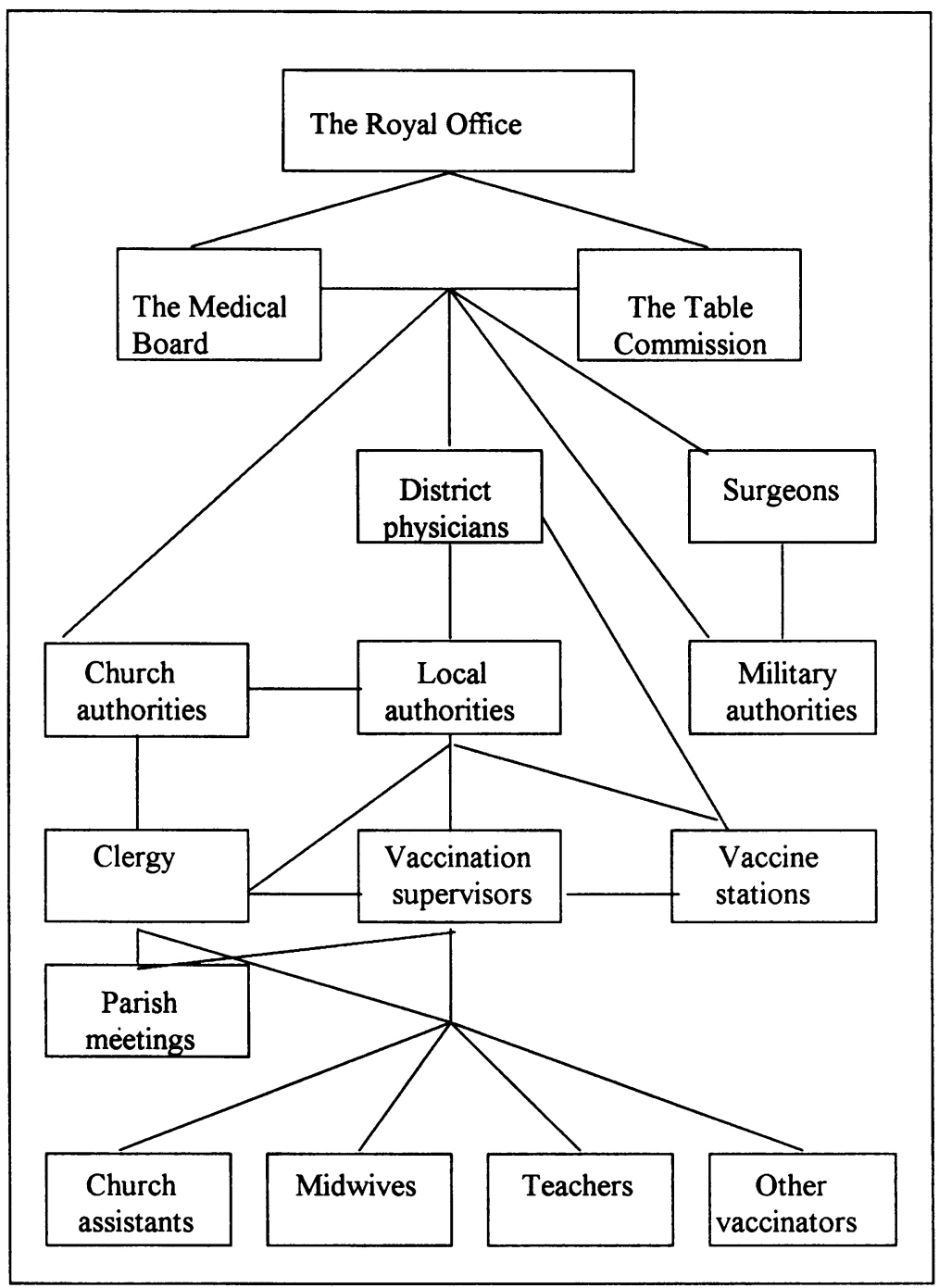

Figure 2: The administration of vaccination in Sweden, started in 1804 , completed in the 1850 s.

Sources: R Norrman, 'Prästerna och vaccinationen. En regional undersökning avseende Uppsala län 1811-1820', Kyrkohistorisk Årsskrift, 1979, pp. 105-6. Kongl. Collegii Medici Kungörelse, om wissa föreskrifter och underrättelser til Vaccinationens almännare och säkrare befrämjande i riket. Med kongl. Maj:ts nådigste samtycke. Gifwen Stockholms slott den 14 Julii 1810, Stockholm, 1810. Kongl. Maj:ts nådiga reglemente för vaccinationen $i$ riket. Gifwit Stockholms slott den 6 mars 1816, Stockholm, 1816. Kungl. Maj:ts Instruction för provinsial-läkare i riket. Gifwen 13 Juni 1822, Stockholm, 1822. Kongl. Sundhets-Collegii till Kongl. Maj:t inlemnade underdåniga förslag till förnyadt Nådigt Reglemente för skyddskoppympningen i Riket, Stockholm, 1852. 


\section{Peter Sköld}

King gave his approval and the money was sent the same week..$^{45}$ Next, the Medical Board approached the physicians. As the Danish Vaccination Committee had done in November $1801{ }^{46}$ the Board requested that physicians provide reports on vaccinations that had already been carried out. ${ }^{47}$ Vice-President Rung took this initiative and at the same time advertised in the newspapers that children were now being accepted for vaccination at the Great Orphanage in Stockholm. ${ }^{48}$

The physicians' first reports were all positive and in October 1802 the Medical Board sent this information to the Royal Office and asked for an official announcement that vaccination would start. ${ }^{49}$ In the same month the Royal Office gave its final approval of the practice..$^{50}$ Moreover, King Gustaf IV Adolf had his daughter Princess Sophia Wilhelmina vaccinated two weeks later. ${ }^{51}$

At the beginning of the nineteenth century, the Medical Board consisted of twelve members and a secretary. ${ }^{52}$ Many, if not all, had previous experience of inoculation. The Medical Board had been under pressure to abolish the monopoly held by the physicians and surgeons. County governors stressed the importance of having church assistants trained in vaccination ${ }^{53}$ and the district physicians began to realize that it was impossible for them to carry out the practice by themselves. ${ }^{54}$ In June 1805 , a Royal letter decreed that all church assistants must learn how to vaccinate. ${ }^{55}$ Physicians thus lost their monopoly and vaccinators were appointed by the clergy or by the parish meetings. District physicians were responsible for distributing vaccine lymph, and this appeared to be a way of keeping some control over the process.

\footnotetext{
${ }^{45}$ Royal letter to the Medical Board, 26 January 1802, Kungl. Maj:ts arkiv, vol. 145, Zetterström, op. cit., note 44 above, pp. 99-200. The King and the Parliament continued to support vaccination. In 1818 a Swedish medical journal stated that "It must be generally concluded that there has not been any other country where vaccination from its beginning was so tenderly supported by the government, so unselfishly and carefully carried out by physicians, and so unhindered and unopposed by the prejudice of the nation, than in Sweden". Kort öfversigt af Svenska

Medicinal-Verket. Medicinsk Tidning, no. 16, 17 December 1818.

${ }^{46}$ Stockholms-Posten, no. 257,10 November 1801. Zetterström, op. cit, note 44 above, pp. 28-9.

${ }^{47}$ Inrikes Tidningar, no. 16, 11 January 1802. Zetterström, op. cit, note 44 above, p. 102.

${ }^{48}$ Medical Board record, 8 February 1802 (AIA:54), Medicinalstyrelsens äldre arkiv, Riksarkivet. Zetterström, op. cit., note 44 above, p. 102 .

49 'Kongl. Collegii Medici underdåniga Utlåtande till Kongl. Maj:t om Vaccinationen',
}

Stockholms-Posten, no. 238, 19 October 1802.

${ }^{50}$ Royal letter, 13 October 1802 (E2:58), Medicinalstyrelsens äldre arkiv, Riksarkivet. Royal letter, 13 October 1802. Inrikes Tidningar, no. 121, 5 November 1802 .

${ }^{51}$ Inrikes Tidningar, no. 133, 3 December 1802.

${ }^{52}$ A Wistrand, Svenska Läkarbefattningar och deras Innehavare, Karlshamn, Svenska Läkareförbundets Förlagsaktiebolag, 1943, pp. 7-8.

${ }^{53}$ Vaccination report from Dr Noraeus,

Kristianstad, 4 October 1804. Vaccination reports 1802-1805 (E4:1), Medicinalstyrelsens äldre arkiv, Riksarkivet.

${ }^{54}$ Letter from the Medical Board to the Royal Office, Stockholm, 13 May 1805, vol. 145 (22:

1420), Kungl. Maj:ts arkiv, Riksarkivet.

${ }^{55}$ Royal letter, 19 June 1805 (E2:60),

Medicinalstyrelsens äldre arkiv, Riksarkivet. A

Wistrand, Författningar angående

Medicinalväsendet $i$ Sverige, Stockholm, P A

Norstedt \& Söner, 1860, vol. 2, p. 54. 


\section{The Organization of Smallpox Vaccination in Sweden}

The Vaccination Law of 1816 stated that vaccinators should be appointed by the parish clergy and approved by the district physicians. Before 1816 vaccinators did not report directly to the Medical Board, instead they sent their lists to the cathedral chapter or the district physician who then compiled regional returns and sent them to Stockholm.

The distribution of cowpox vaccine was crucial for the efficiency of the vaccination system. ${ }^{56}$ The Vaccination House in Stockholm had the ultimate responsibility of keeping and providing fresh vaccine. In 1802, Dr Almroth sent vaccine lymph and needles to all who requested them. ${ }^{57}$ The following year the Medical Board realized that one vaccine station could not serve the entire country and asked the Royal Office to establish others in Uleåborg, Åbo, Karlskrona, Lund and Gothenburg. ${ }^{58}$ Since the first two towns were included in Finland after the separation in 1809 , other stations were required. Permission was given for these to be established in 1812 in Norrköping, Jönköping, Örebro, Gävle and Härnösand. ${ }^{59}$ In 1813, Växjö was added to the list ${ }^{60}$ and in 1814 , Visby. ${ }^{61}$ The Vaccination Law of 1816 also included Umeå and Falun. ${ }^{62}$ However, several of these establishments had difficulties in maintaining vaccine matter throughout the year. Stockholm, Gothenburg and Lund sent out most vaccine. In 1854, the number of vaccine stations was limited to eight, and those in Umeå, Falun, Örebro and Jönköping were closed. ${ }^{63}$ Because both Umeå and Falun had served the northern parts of Sweden, complaints forced the Medical Board to establish a vaccine station in Östersund in $1873 .{ }^{64}$ The Vaccine stations were important in the overall organization, but for all vaccinators to be supplied, it was also necessary that the fundamentals of the organization were stable. Thus, the district physicians were active in distributing vaccine, and informal networks were created where vaccinators sent vaccine to each other. This was faster and easier than obtaining it from the physician or the vaccine station. ${ }^{65}$ Even if some problems occurred, distribution never became an important obstacle to the practice of vaccination.

\footnotetext{
${ }^{56}$ Production and distribution of consistently high quality vaccine were major problems also during the first WHO campaign to eradicate smallpox in 1959. J W Hopkins, The eradication of smallpox: organizational learning and innovation in international health, Boulder, $\mathrm{CO}$, Westview, 1989 , p. 7; J G Rigau-Pérez, 'Strategies that led to the eradication of smallpox in Puerto Rico, 1882-1921', Bull. Hist. Med., 1985, 59 (1): 75-88.

${ }^{57}$ Vaccination report from Dr Almroth, Stockholm, 30 November 1802, Vaccination reports 1802-1805 (E4:1), Medicinalstyrelsens äldre arkiv, Riksarkivet.

${ }^{58}$ Medical Board record, 20 May 1803 (A1A: 55 (423-30:3)), Medicinalstyrelsens äldre arkiv, Riksarkivet.

${ }^{59}$ Letter from the Medical Board to the Royal Office, Stockholm, 16 November 1812, vol. 145 (26:668), Kungl. Maj:ts arkiv, Riksarkivet.
}

\footnotetext{
${ }^{60}$ Letter from the Medical Board to the Royal Office, Stockholm, 2 November 1812, vol. 145 (28:641), Kungl. Maj:ts arkiv, Riksarkivet.

${ }^{61}$ Letter from the Medical Board to the Royal Office, Stockholm, 29 August 1814, vol. 145 (28: 540), Kungl. Maj:ts arkiv, Riksarkivet.

${ }^{62}$ Kongl. Maj:ts nådiga reglemente för vaccinationen i riket. Gifwit Stockholms slott den 6 Mars 1816, Stockholm, 1816.

${ }^{63}$ Bidrag till Sveriges Officiella Statistik (BiSOS) 1851-60, vol. K Health care, Stockholm, 1861, p. 58.

${ }_{64}$ Bidrag till Sveriges Officiella Statistik (BiSOS) 1873, vol. K Health care, Stockholm, 1873 , p. 63.

${ }^{65}$ Letter from the Medical Board to the Royal Office, Stockholm, 23 October 1826, vol. 145 (52: 462), Kungl. Maj:ts arkiv, Riksarkivet.
} 


\section{Peter Sköld}

In the $1840 \mathrm{~s}$, the need for revaccination was stressed because immunity lasted between ten and fifteen years only, so the Medical Board decided to revaccinate men called up for military service. In 1849 , all military physicians were instructed to vaccinate every recruit, compile records and send these to the Medical Board. ${ }^{66}$ Vaccination of the military complemented child vaccination well, and increased immunity against smallpox in Sweden.

\section{The Medical Profession}

In the organizational hierarchy, the district physicians were positioned under the Medical Board. This group might be compared to what Frank Fenner and his coauthors list as the second important factor: a dedicated and competent staff. ${ }^{67}$ Because of their medical knowledge, the district physicians were given the authority to confirm the right to vaccinate, and they also held the most important position in the administrative system. They were consulted by the local supervisors, and scrutinized the records of every parish in the district, which were sent to them by the county governor. Their reports summarized the events in each district, and were often referred to by the Medical Board. ${ }^{68}$

Most district physicians were enthusiastic about vaccination and started to organize its practice in their districts. As we have seen, some differences occurred, but throughout the country the basic structure remained the same. ${ }^{69}$ This had been set out in the plan presented by the Medical Board in 1802, which was identical to that in the Vaccination Law of $1816 .^{70}$ By waiting, the authorities had been able to

\footnotetext{
${ }^{66}$ Kongl. Maj:ts Sundhets-Collegii Circulaire till wederbörande Chefs-Embeten, angående Revaccinationen af Recrüter; utfärdadt den 15 Februari 1849, Stockholm, 1849.

${ }^{67}$ F Fenner, D A Henderson, I Arita, Z Jezek, I D Ladnyi, Smallpox and its eradication, Geneva, World Health Organization, 1988, p. 515.

${ }^{68}$ Norrman, op cit., note 1 above, pp. 105-6. Kongl. Collegii Medici kungörelse, om wissa föreskrifter och underrättelser til vaccinationens almännare och säkrare befrämjande $i$ riket. Med Kongl. Maj:ts nådigste samtycke. Gifwen Stockholms slott den 14 Julii 1810, Stockholm, 1810. Kongl. Maj:ts nådiga reglemente för vaccinationen i riket. Gifwit Stockholms slott den 6 mars 1816, Stockholm, 1816. Kungl. Maj:ts Instruction för provinsial-läkare i riket. Gifwen 13 Juni 1822, Stockholm, 1822, § 12. Kongl. Sundhets-Collegii till Kongl. Maj:t inlemnade underdåniga förslag till förnyadt Nådigt Reglemente för skyddskoppympningen $i$ Riket, Stockholm, 1852, pp. 8-9. In renewed instructions for vaccination in Sweden some of the responsibility previously held by district physicians was given to the county governors. The physicians were to supply the vaccinators with vaccine lymph and send in reports.
}

Nevertheless, they were dominant in the drawing up of the new instruction. Medicinalstyrelsens underdaniga skrifvelse med anledning af de särskilda yttranden, som af Kongl. Maj:t infordrats öfver Styrelsens förslag till nytt vaccinationsreglemente, Supplement to Hygiea, 1896, 58 (1): 1-107, p. 107.

${ }^{69}$ During their travels to carry out vaccination, district physicians were given an opportunity to examine and better understand the situation, especially in the northern counties. This was of importance for the organization of medical care in general. L Öhman, Hur sjukvården kom till norr. En kulturhistorisk skildring med utgångspunkt från mellersta Lappland, Växjö, Tore Säll InfoMedia, 1987, pp. 103-4.

${ }^{70}$ Another initiative was taken by the county governor of the district of Örebro in 1815. The plan presented was approved by the Medical Board, who even wanted to make it the general rule in Sweden. As with the other district organization plans, the basic structure was found in the Vaccination Law of 1816. Letter from the Medical Board to the Royal Office, Stockholm, 27 February 1815, vol. 145 (30:107), Kungl. Maj: ts arkiv, Riksarkivet. 


\section{The Organization of Smallpox Vaccination in Sweden}

produce a solution as a response not only to a directive from above, but also to demands from below. This increased the likelihood that the plan would be accepted and function.

\section{Local Authorities and the Clergy}

In 1804, every parish was instructed to appoint a vaccinator and, in 1812, a supervisor as well. The latter was responsible for the annual vaccination report which each parish had to send to the district physician and the county governor. The vaccine supervisors were a newly established group in the health care system. They had no equivalents in public health in Sweden or any other country. The Vaccination Law of 1816 stated that the local supervisors should ensure that every child was vaccinated before its second birthday. The supervisors made sure that after seven or eight days the vaccinators revisited those who had been vaccinated, the clergy kept detailed records of both vaccinated and unvaccinated children, and these reports were sent to the county governor and the diocesan administration. ${ }^{71}$ The supervisors were by and large persons in authority, such as barons and those highly placed in the army and the administration, but some women were also given this responsibility, although they mostly came from the same social groups as the men. ${ }^{72}$ Later the clergy and local civil servants dominated the lists of supervisors. ${ }^{73}$ This local administration of vaccination used the existing parish system, with its meetings, for information, appointments, financial discussion and control. The system divided Sweden into more than 2,400 administrative units, each containing an average of 1,000 persons or 220 households each. ${ }^{74}$ This was perhaps the most unique part of the Swedish vaccination system and definitely one of the most important.

At the local level, the pioneers were mainly clergymen. Most parishes reported that the pastor had demonstrated the new method, and often had his own children vaccinated first. ${ }^{75}$ The early promotion by the clergy is described in detail by the

\footnotetext{
${ }^{71}$ Kongl. Maj:ts nådiga reglemente för vaccinationen $i$ riket. Gifwit Stockholms slott den 6 Mars 1816, Stockholm, 1816.

${ }^{72}$ Vaccination report from the southern part of Stockholm district 1807, Vaccination reports 1808 (E4:4), Medicinalstyrelsens äldre arkiv, Riksarkivet.

${ }^{73}$ Vaccine organization in Härjedalen district 1851, Papers concerning vaccination 1851-58, vol. 1., Provinsialläkarens arkiv (District Physicians archive), Östersunds Landsarkiv. In the late nineteenth century the supervisors were criticized. In 1892 Dr Möller claimed that they had signed a record of vaccinated children without examining it. A H T Möller, 'Om förändringar i nu gällande stadgar angående skyddsympningen', Eira. Tidskrift för helso- och sjukvård, 1892, 16 (22): $693-99$, p. 695. See also 'Det omredigerade förslaget till nytt vaccinations-reglemente', Eira.
}

Tidskrift för helso- och sjukvård, 1896, 20 (2): 184-9.

${ }^{74}$ When the first handbook on vaccination was distributed in 1813, Nils Rosén von Rosenstein estimated that the number of churches in Sweden was 2,444. Report from Nils Rosén von Rosenstein, Stockholm, 26 May 1813, Excerpts from vaccination reports 1817-1837 (E12B:3), Medicinalstyrelsens äldre arkiv, Riksarkivet.

${ }^{75} \mathrm{See}$, for example, the record of a meeting in Säresta parish on 12 December 1802, Vaccination report from Rev. Olof Haggren, Nordhammar parish, 30 September 1802, Vaccination reports 1802-1805 (E4:1), Medicinalstyrelsens äldre arkiv, Riksarkivet. G Wikmark, Edvard Rhén. Lapplandspräst och Upplandsprost, Skytteanska Samfundets Handlingar Nr 36, Kungl. Umeå, 1989, pp. 12-16 and 44-50. 


\section{Peter Sköld}

Reverend J P Wallensteen in the parish of Kuddby. He had read about vaccination in the newspapers and then preached on the method from the pulpit. He tried to convince the audience using concern, rational arguments, and religion; however, he was not successful. He then decided to walk from village to village talking to members of every household, employing pressure, threats, enticements, pleading and praise. This work occupied him the whole of the summer. He met with great resistance and only one child was vaccinated in both 1802 and 1803. In 1804, he decided to call for the district physician, Nordin. Together they persuaded some parents to have their children vaccinated, but since no one came and showed the pustules, Wallensteen and Nordin had to return to the villages to seek them out. Many parents hid vaccinated children or went into the forest when they saw the physician and the pastor coming.

Wallensteen gave various explanations for this opposition and distrust. He also noted that the first families to have their children vaccinated were reproached by others. Although all the state institutions - the Royal Office, the Medical Board, the county governors and the cathedral chapters-backed vaccination, it was very difficult to change public attitudes. A frequently heard comment was: "Well, it is not obligatory, if it was, no one could refuse it". As a result, and after eighteen months of fruitless work, the pastor understood that he had to employ a new tactic:

With regard to enforcement, I had always found the language of power to be most efficient. I used it in this matter too, for the excellent objective and the effectiveness of this method justified its use. My aim was to endure whatever might happen to me in order to make vaccination complete. After one and a half years of troublesome efforts I got permission from the Royal Office to present vaccination as compulsory. After reading from the pulpit, I would strike both hands with all my strength on the pulpit, stamp, shout loudly as if enraged, reminding the congregation how. often they have heard what I am talking about, not only from the county governor and all such enlightened people, but also from God and the King, that they now have heard the King's gracious approval for all this, so I no longer ask, but order, and if obedience does not follow, the resister shall be forced to comply with help from the police etc. I call these resisters child killers; and if any child withheld from vaccination dies of smallpox, it will be buried on the north side of the church with a notice on the grave giving the reason for this; that in the case of such parents the newspapers shall be notified of their crime; a public record of their disgrace will be kept after their death etc. etc. After this, the next vaccination session was announced, and the names read out of those who were expected to attend, together with those who had previously been vaccinated, and I also said that henceforth all vaccinations will be announced in this way. The announcements after this have been obeyed, with a carefulness which cannot be praised enough;.$^{76}$

After this event in his parish, Wallensteen could confidently state that vaccination had been successful and that attitudes had also changed in neighbouring parishes, He was so sure of the great value of vaccination that he promised 100 riksdaler to

\footnotetext{
${ }^{76}$ Vaccination report from the Rev. J P Wallensteen, Kuddby, 26 April 1808, Vaccination
}

reports $1808-1809$ (E4:4, no. 45),

Medicinalstyrelsens äldre arkiv, Riksarkivet. 


\section{The Organization of Smallpox Vaccination in Sweden}

anyone who could prove that a vaccinated child had later been infected by smallpox. Economic enticements or threats seem to have played a role in the implementation of vaccination. From Garphyttan, it was reported that no one wanted to have their children vaccinated, but when the pastor and the local iron foundry inspector together decided that those who resisted it would lose their subsidies for seed, everyone appeared..$^{77}$

The clergy certainly played an important role when vaccination was introduced in Sweden. They were the link between the authorities and the parishes, and they were able to persuade the local people of its value. The authorities understood this at an early stage, and incorporated them into the organization for vaccination. Moreover, the Medical Board suggested in 1811 that those clergymen who had actively supported vaccination should be favoured when they applied for promotion. ${ }^{78}$

\section{Urban and Rural Vaccination}

The factor that most influenced smallpox mortality in Sweden in the nineteenth century was vaccination..$^{79}$ This preventive method was generally accepted; however, it was carried out in a different and less efficient way in Stockholm. The capital had a considerably higher smallpox mortality than the rest of the country, largely due to some crucial differences in the organization of vaccination. These included compulsory regulation, the monopoly system, the role of local government and the clergy, and the report system and records.

Apart from extensive practice in 1805 , vaccination never reached the same level in Stockholm as the average for other parts of Sweden. This first year of compiled vaccination records for the capital reported only 10 per cent of children vaccinated, while the average for the rest of the country was almost 40 per cent. ${ }^{80}$ The physicians claimed that the rate was higher than the numbers showed, because their colleagues outside the Vaccination House and the four vaccine depots did not send in their registers. In fact, as no vaccinations were permitted outside these five places, there were no more to report. The Medical Board also had difficulty in getting the physicians responsible for vaccination to send in their registers. Dr Gistrén admitted in 1806 that he had kept no information about the name, sex or age of his patients, and no note of the dates of vaccination. He had not believed that it was important ${ }^{81}$ Between 1811 and 1845 , the physicians did not report any official vaccination rates in Stockholm. The most common explanation was a lack of registers.

\footnotetext{
${ }^{77}$ Vaccination report from Johan August Lenaeus Knutsson, Garphytte bruk, 4 February 1813, Vaccination reports 1812:2 (E4:7), Medicinalstyrelsens äldre arkiv, Riksarkivet.

${ }^{78}$ Letter from the Medical Board to the Royal Office, Stockholm, 12 January 1811, vol. 145 (25: 5), Kungl. Maj:ts arkiv, Riksarkivet.

${ }^{79}$ Sköld, op. cit., note 21 above, pp. 501-15.
}

\footnotetext{
${ }^{80}$ Sjukdomars härjande åren 1795-1812, Vaccinerade 1804-8, 1811-12, BIIc:1, Statistiska Centralbyråns arkiv, den äldre

Tabellkommissionen (the older archive of Tabellkommissionen), No. 29, Riksarkivet. ${ }^{81}$ Vaccination report from Dr Gistrén, Vaccination reports 1806, E4:2(60), Medicinalstyrelsens äldre arkiv, Riksarkivet.
} 


\section{Peter Sköld}

Table 1

The organization of inoculation and vaccination, Stockholm and Sweden 1756-1900

\begin{tabular}{l|l|l|l}
\hline & $\begin{array}{l}\text { Inoculation } \\
\text { Stockholm and Sweden }\end{array}$ & $\begin{array}{l}\text { Vaccination } \\
\text { Stockholm }\end{array}$ & $\begin{array}{l}\text { Vaccination } \\
\text { Sweden }\end{array}$ \\
\hline Responsible & Physicians & Physicians & Local governments \\
\hline Monopoly & Only physicians allowed & Only physicians allowed & $\begin{array}{l}\text { No restrictions, } \\
\text { mostly laymen }\end{array}$ \\
\hline Locality & $\begin{array}{l}\text { Institute (Stockholm) } \\
\text { Homes (Sweden) }\end{array}$ & Inoculation House & Homes \\
\hline Care and charge & 14 days & $\left.\begin{array}{l}14 \text { days }(1802-40) \\
1-2 \text { days }(1840-\end{array}\right)$ & No care-taking \\
\hline Reports & No records & No records & $\begin{array}{l}\text { Records from all } \\
\text { parishes annually }\end{array}$ \\
\hline Law force & No laws & Strong law force & Slight law force \\
\hline Result & Low rates & Low rates & High rates \\
\hline
\end{tabular}

Source: P Sköld, The two faces of smallpox: a disease and its prevention in eighteenth-and nineteenthcentury Sweden, Umeå, Demographic Database, 1996, pp. 467-78.

The Medical Board appreciated that Stockholm was different from the rest of the country. Since the church organization with small parishes did not function in the capital, the Board decided that all vaccinations should take place at the Vaccination House. When the Royal Office asked them in 1804 if it was necessary for all vaccinated children to be kept at the institution for several days, the Medical Board replied that the treatment required it. The Royal Office also raised the possibility of paying poor people for the vaccination of their children. The physicians stated that a fourteen-day stay at the House was necessary for each vaccinated child and the budget for the children's care, including food, was not sufficient to cover payments to their parents. ${ }^{82}$ This showed that the physicians had not learned from the experience of inoculation. Most people were interested only if they could take care of their children at home. We also know that rich people hesitated to leave their children in the same place as poor ones. There is another reason why the Vaccination House was viewed suspiciously. In 1805, the local authorities in Stockholm (över-ståthållare ämbetet) decided that all persons

\footnotetext{
${ }^{82}$ Letter from the Medical Board to the Royal Office, 4 June 1804, vol. 145 (1076), Kungl. Maj:t arkiv, Riksarkivet.
} 


\section{The Organization of Smallpox Vaccination in Sweden}

infected by smallpox should be brought to the House. ${ }^{83}$ There was then a risk that the children who came for vaccination would be infected by smallpox virus first. The choice of this institution for the practice of vaccination was certainly unfortunate. The Medical Board had proposed this measure well aware of the reluctance among the majority of poor people to send their children to it. ${ }^{84}$ This proved to be a problem during most of the nineteenth century. Dr Gustaf Grähs concluded in his report during the severe epidemic in 1874 that the fear of hospitals was enormous, and that there was a strong desire among the public to take care of infected persons in their own homes. ${ }^{85}$

As early as 1784, Dr Peter Jonas Bergius had suggested that inoculation ought to be enforced by law, at least in the capital. ${ }^{86}$ This never became a reality but, in 1805 , the local authorities in Stockholm decided that those who did not report smallpox infection should be fined 3 riksdaler 16 skilling. ${ }^{87}$ There were no similar laws in the rest of Sweden and what is more important (and not commented on) is the fact that on 7 April 1815 Stockholm actually made vaccination compulsory before the law was passed in the Swedish Parliament. ${ }^{88}$ This action was taken by a group of physicians and local officials, who had realized that it was much more difficult to carry out vaccination in Stockholm than in the countryside.

The physicians in Stockholm did not have the same contact with the poor as did the clergy and their assistants in most parts of Sweden. Neither did the public trust them as much as the more familiar pastors or local leaders in the countryside. The social network that established considerable control did not exist in the same way in Stockholm. In the countryside it was impossible to keep smallpox infection secret. In Stockholm, Dr Hardtman found fourteen infected children in one house in 1807. He took twelve of them to the Vaccination House, but thirteen infected children were later found in the same block. ${ }^{89}$ The city authorities realized that it was very difficult to survey the smallpox immunity status of the inhabitants. Vaccination was enforced by law, and in 1817 the Health Board suggested that the poor should carry health passports. Those who could not show a vaccination certificate should be vaccinated immediately and no one was able to get a job paid by the city administration without the same proof. ${ }^{90}$

\footnotetext{
${ }^{83}$ Öfwer-Ståthållare-Embetets Kungörelse, om Det af Kongl. Maj:t, jemte widtagne anstalter til Vaccinationens befrämjande här $i$ staden, tillika utsatte answar för dem, som underlåta at anmäla yppad naturlig koppsmitta, Stockholm, 11 April 1805.

${ }^{84}$ Letter from the Medical Board to the Royal Office, 16 March 1805, vol. 145 (715), Kungl. Maj:ts arkiv, Riksarkivet.

${ }^{85}$ Annual report from the first town physician, Gustaf Grähs, Stockholm, 1874, Annual reports from district physicians, E5A:44, Medicinalstyrelsens äldre arkiv, Riksarkivet.

${ }^{86} \mathrm{P}$ J Bergius, 'Anmärkningar i anledning af sista Koppe-epidemin',in Kongl. Vetenskaps Academiens Nya Handlingar, 1784, 5: 154-55.
}

\footnotetext{
${ }^{87}$ Öfwer-Ståthållare-Embetets Kungörelse, om Det af Kongl. Maj:t, jemte widtagne anstalter til Vaccinationens befrämjande här $i$ staden, tillika utsatte answar för dem, som underlåta at anmäla yppad naturlig koppsmitta, Stockholm, 11 April 1805.

${ }^{88}$ Öfwer-Ståthållare-Embetets Kungörelse om answar för dem som underlåta at Waccinera sine barn, Stockholm, 7 April 1815.

${ }^{89}$ Letter from the Medical Board to the Royal Office, 26 February 1807, vol. 145 (533), Kungl. Maj:ts arkiv, Riksarkivet.

${ }^{90}$ Letter from Sundhetskollegium to the Royal Office, 14 February 1817, vol. 145, Kungl. Maj:ts arkiv, Riksarkivet.
} 


\section{Peter Sköld}

Another difference between vaccination in Stockholm and the rest of Sweden was its organization. In the countryside, we know that it was mostly church assistants who carried out the operation, but in Stockholm the physicians continued with the monopoly system that had excluded all other persons from practising inoculation. Dr Trafvenfeldt stated in 1806 that there were hundreds of physicians in Stockholm who could vaccinate, ${ }^{91}$ and the monopoly was prolonged in 1852 for a further period with the same argument. While midwives elsewhere were common practitioners of vaccination, in Stockholm they were said to pose a serious obstacle to it. ${ }^{92}$

In 1816, the local authorities decided that the clergy should compile records on all new-born children and send them to the church administration (konsistorium) in Stockholm, which in turn would send the information to local authorities in the capital, who would send this on to the Medical Board. Then all practising physicians would come to the Health Board and fill in their vaccination records, so the records could be sent back to the local authorities, who had to see that unvaccinated children were brought to the Vaccination House. ${ }^{93}$ This was an unnecessarily complicated reporting system, which stated who was responsible for the different parts of it without declaring who had the main responsibility. This was commented upon in 1852 when the new instruction gave the four physicians at the vaccine depots sole responsibility. ${ }^{94}$

\section{The Key to Success: Organization and the Church}

The introduction of vaccination had parallels with the introduction of inoculation. ${ }^{95}$ The Medical Board did not act until pressure to do so came from initiatives in other countries, from the pioneering practice of other physicians, and from requests by the Royal Office. Official approval soon followed and the district physicians were ordered to begin the practice and to send in reports. As in many other European countries, a Vaccination Committee was set up. In Sweden, however, the health authorities had strong control over vaccination.

The promotional work by the Medical Board and by individual enthusiasts at local level, parish meetings with responsibility for it, the support and active engagement by the clergy, and campaigns in the newspapers all helped to gain acceptance for vaccination. Moreover, friends and relatives with vaccinated children could influence

\footnotetext{
${ }^{91}$ Vaccination report from Carl Trafvenfeldt, 28 June 1806, Vaccination reports, E4:2 (58), Medicinalstyrelsens äldre arkiv, Riksarkivet.

${ }^{92} \mathrm{~K}$. Sundhets-Collegii till Kongl. Maj:t inlemnade underdåniga förslag till särskildta föreskrifter rörande skyddskoppympningen i hufvudstaden, Stockholm, 21 June 1852.

${ }_{93}$ Över-Ståthållare-Embetets Kungörelse om åtskilliga ytterligare åtgärder till Waccinationens
}

\author{
befodran och framgaing inom hufwudstaden, \\ Stockholm, 15 January 1816. \\ ${ }^{94} \mathrm{~K}$. Sundhets-Collegii till Kongl. Maj:t \\ inlemnade underdåniga förslag till särskildta \\ föreskrifter rörande skyddskoppympningen $i$ \\ hufvudstaden, Stockholm, 21 June 1852. \\ ${ }_{95}$ A Emch-Dériaz, 'L'inoculation justifiée-or \\ was it?' Eighteenth-Century Life, 1983, 7 (2): \\ $65-72$.
}




\section{The Organization of Smallpox Vaccination in Sweden}

parents to have their children immunized. We must, however, ask to what extent an individual was in control of the factors that were important for a positive response to vaccination. In the early nineteenth century, this control was considerable, given that vaccination was voluntary. But, from 1816 when vaccination became compulsory, the situation was different. Then rejecting the method was a serious matter, condemned by the churches and punishable as a crime.

During the fifteen years of vaccination before it was enforced by the law of 1816 , Swedish counties showed great differences. ${ }^{96}$ In a study on relations between homicide, murder and suicide, and a set of other behavioural variables, Johan Söderberg has considered vaccination as an expression of the care that parents gave their children. He found vaccination between 1816 and 1855 to be slightly correlated with homicide and murder. More interestingly, he also found significant correlations between vaccination and low fertility $(-0.54)$, and literacy $(0.64)$. The number of midwives was also greater in counties with high vaccination rates. Söderberg states that the western counties with lower rates were characterized by a stronger religious influence and a fatalistic attitude. ${ }^{97}$

Two sets of variables have been chosen to find a correlation with vaccination (A) between 1816 and 1820. The first is demographic and organizational; (B) inhabitants per square mile $(10 \times 10$ kilometres $)$ estimates crudely the level of isolation of parishes and the distances a vaccinator had to travel. Because the church was an important part of the vaccination organization, the standardized numbers of (C) clergy and (D) church assistants are estimated. The medical system was in an early phase of development; nevertheless, the standardized numbers of $(E)$ physicians and surgeons are given to determine if this was important for the extent of vaccination.

When vaccination did not take place was that the result of a lack of parental care and a manifestation of a moral attitude, where the lives of infants and children were not as highly valued as in counties where vaccination was more successfully carried out? Or was this a reflection of the fatalistic attitude, where concern about children was partly understood as ineffective? The second set constitutes behavioural variables, (F) infant mortality rates, $(\mathrm{G})$ children choked to death, $(\mathrm{H})$ illegitimate children and (I) infant deaths from an unknown disease. The last variable needs comment because a great number of children died from what was simply called "unknown disease". We know very little about the real causes of these deaths. Söderberg, among others, relates these fatalities to a lack of care on the part of adults. ${ }^{98}$ The choking

\footnotetext{
${ }^{96}$ Sköld, op. cit., note 21 above, p. 571.

${ }^{97}$ Söderberg, op. cit., note 11 above, pp. $154-8,228-36,244-6$.
}

\footnotetext{
${ }^{98}$ Ibid, pp. 148-53. H Gahn, Moralstatistiska uppgifter i Frihetstidens Tabellverk. En demografisk studie, Uppsala, K W Appelbergs, 1915, pp. 20-1.
} 


\section{Peter Sköld}

Table 2

Rates for demographic, organizational and behavioural variables in the 24 Swedish counties $1816-1820$

\begin{tabular}{|c|c|c|c|c|c|c|c|c|c|}
\hline & A & B & $\mathrm{C}$ & $\mathrm{D}$ & $\mathrm{E}$ & $\mathrm{F}$ & G & $\mathrm{H}$ & I \\
\hline Stockholm & 76.4 & 1402 & 180 & 227 & 11.8 & 233 & 271 & 79 & 283 \\
\hline Uppsala & 75.0 & 1567 & 188 & 235 & 4.0 & 196 & 308 & 82 & 428 \\
\hline Södermanland & 92.8 & 1617 & 159 & 165 & 7.6 & 150 & 59 & 74 & 325 \\
\hline Östergötland & 78.0 & 1534 & 162 & 230 & 6.7 & 168 & 525 & 67 & 191 \\
\hline Jönköping & 61.9 & 1152 & 153 & 159 & 5.3 & 155 & 754 & 40 & 196 \\
\hline Kronoberg & 73.1 & 1050 & 148 & 129 & 1.1 & 192 & 829 & 47 & 246 \\
\hline Kalmar & 77.0 & 1375 & 127 & 146 & 5.3 & 158 & 935 & 53 & 311 \\
\hline Gotland & 86.3 & 1067 & 228 & 343 & 0 & 151 & 20 & 65 & 340 \\
\hline Blekinge & 53.6 & 2185 & 64 & 62 & 3.5 & 187 & 286 & 73 & 362 \\
\hline Kristianstad & 77.5 & 2200 & 107 & 88 & 3.3 & 158 & 472 & 60 & 554 \\
\hline Malmöhus & 70.0 & 3624 & 133 & 91 & 1.4 & 150 & 281 & 61 & 589 \\
\hline Halland & 69.1 & 1674 & 98 & 91 & 0 & 170 & 410 & 36 & 481 \\
\hline \multicolumn{10}{|l|}{ Göteborg och } \\
\hline Bohus & 42.3 & 2238 & 73 & 107 & 3.1 & 184 & 144 & 59 & 303 \\
\hline Älvsborg & 67.1 & 1336 & 110 & 154 & 0.6 & 142 & 385 & 39 & 401 \\
\hline Skaraborg & 74.1 & 1812 & 157 & 221 & 2.9 & 164 & 705 & 42 & 393 \\
\hline Värmland & 86.4 & 865 & 78 & 107 & 2.9 & 157 & 860 & 81 & 485 \\
\hline Örebro & 57.0 & 1234 & 97 & 117 & 3.3 & 181 & 136 & 74 & 320 \\
\hline Västmanland & 65.0 & 1256 & 182 & 159 & 10.5 & 206 & 253 & 88 & 319 \\
\hline Kopparberg & 47.6 & 409 & 88 & 82 & 6.1 & 130 & 179 & 52 & 498 \\
\hline Gävleborg & 81.1 & 459 & 111 & 118 & 1.3 & 151 & 119 & 66 & 592 \\
\hline Västernorrland & 69.5 & 292 & 154 & 162 & 0 & 228 & 46 & 48 & 639 \\
\hline Jämtland & 73.5 & 80 & 135 & 207 & 14.4 & 130 & 319 & 54 & 626 \\
\hline Västerbotten & 68.0 & 49 & 108 & 127 & 6.2 & 228 & 28 & 43 & 649 \\
\hline Norrbotten & 46.8 & 43 & 89 & 101 & 3.1 & 239 & 15 & 62 & 648 \\
\hline
\end{tabular}

$\mathrm{A}=$ Vaccinated (percentage of children born the previous year)

$\mathrm{B}=$ Inhabitants per square mile $(10 \times 10$ kilometres $)$

$\mathrm{C}=$ Clergy per 100,000 inhabitants

$\mathrm{D}=$ Church assistants per 100,000 inhabitants

$\mathrm{E}=$ Physicians and surgeons per 100,000 inhabitants

$\mathrm{F}=$ Infant mortality rate per 1,000 born

$\mathrm{G}=$ Children choked to death per 100,000 born

$\mathrm{H}=$ Illegitimate children per 1,000 born

$\mathrm{I}=$ Infant deaths from unknown cause per 1,000 deaths

Sources: Population records and mortality records for Sweden 1816-1820, Research Archive, Umeå University. C af Forsell, Statistik öfver Sverige. Grundad på offentliga handlingar, Facsimile 1833, 2nd ed., Stockholm, Rediviva, 1978. 


\section{The Organization of Smallpox Vaccination in Sweden}

Table 3

Ranking numbers for the rates for demographic, organizational and behavioural variables in the 24 Swedish counties 1816-1820

\begin{tabular}{|c|c|c|c|c|c|c|c|c|c|}
\hline & A & B & $\mathrm{C}$ & $\mathrm{D}$ & $\mathrm{E}$ & $F$ & G & $\mathrm{H}$ & I \\
\hline Stockholm & 8 & 10 & 4 & 4 & 2 & 23 & 11 & 21 & 4 \\
\hline Uppsala & 9 & 8 & 2 & 2 & 10 & 19 & 14 & 23 & 14 \\
\hline Södermanland & 1 & 7 & 6 & 6 & 4 & 4 & 5 & 19 & 9 \\
\hline Östergötland & 5 & 9 & 5 & 5 & 5 & 13 & 19 & 17 & 1 \\
\hline Jönköping & 19 & 15 & 9 & 9 & 8 & 8 & 21 & 3 & 2 \\
\hline Kronoberg & 12 & 17 & 10 & 10 & 20 & 18 & 22 & 6 & 3 \\
\hline Kalmar & 7 & 11 & 13 & 13 & 8 & 10 & 24 & 9 & 6 \\
\hline Gotland & 3 & 16 & 1 & 1 & 22 & 6 & 2 & 15 & 10 \\
\hline Blekinge & 21 & 4 & 24 & 24 & 11 & 17 & 13 & 18 & 11 \\
\hline Kristianstad & 6 & 3 & 17 & 17 & 12 & 10 & 18 & 12 & 18 \\
\hline Malmöhus & 13 & 1 & 12 & 12 & 18 & 4 & 12 & 13 & 19 \\
\hline Halland & 15 & 6 & 18 & 18 & 22 & 14 & 17 & 1 & 15 \\
\hline \multicolumn{10}{|l|}{ Göteborg och } \\
\hline Bohus & 24 & 2 & 23 & 23 & 14 & 16 & 8 & 11 & 5 \\
\hline Älvsborg & 17 & 12 & 15 & 15 & 21 & 3 & 16 & 2 & 13 \\
\hline Skaraborg & 10 & 5 & 7 & 7 & 16 & 12 & 20 & 4 & 12 \\
\hline Värmland & 2 & 18 & 22 & 22 & 16 & 9 & 23 & 22 & 16 \\
\hline Örebro & 20 & 14 & 19 & 19 & 12 & 15 & 7 & 19 & 8 \\
\hline Västmanland & 18 & 13 & 3 & 3 & 3 & 20 & 10 & 24 & 7 \\
\hline Kopparberg & 22 & 20 & 21 & 21 & 7 & 1 & 9 & 8 & 17 \\
\hline Gävleborg & 4 & 19 & 14 & 14 & 19 & 6 & 6 & 16 & 20 \\
\hline Västernorrland & 14 & 21 & 8 & 8 & 22 & 21 & 4 & 7 & 22 \\
\hline Jämtland & 11 & 22 & 11 & 11 & 1 & 1 & 15 & 10 & 21 \\
\hline Västerbotten & 16 & 23 & 16 & 16 & 6 & 21 & 3 & 5 & 24 \\
\hline Norrbotten & 23 & 24 & 20 & 20 & 14 & 24 & 1 & 14 & 23 \\
\hline
\end{tabular}

$A=$ Vaccinated (percentage of children born the previous year)

$\mathrm{B}=$ Inhabitants per square mile $(10 \times 10$ kilometres $)$

$\mathrm{C}=$ Clergy per 100,000 inhabitants

$\mathrm{D}=$ Church assistants per 100,000 inhabitants

$\mathrm{E}=$ Physicians and surgeons per 100,000 inhabitants

$\mathrm{F}=$ Infant mortality rate per 1,000 born

$\mathrm{G}=$ Children choked to death per 100,000 born

$\mathrm{H}=$ Illegitimate children per 1,000 born

I $=$ Infant deaths from unknown cause per 1,000 deaths

Sources: Population records and mortality records for Sweden 1816-1820, Research Archive, Umeå University. C af Forsell, Statistik öfver Sverige. Grundad på offentliga handlingar, Facsimile 1833, 2nd ed., Stockholm, Rediviva, 1978. 


\section{Peter Sköld}

of children has also been associated with a variety of cultural and social behaviour and this cause of death reveals regional differences. ${ }^{99}$

Low ranking numbers show what is considered to be a positive result. For vaccination, this means a high percentage; for inhabitants per square Swedish mile, a low number (because there was less smallpox mortality in a population with lower density); for clergy, physicians and surgeons, it means high rates; and for infant mortality, children choked to death, illegitimate children, and infant deaths from unknown disease it means low rates.

If we look at the best vaccinated county, Södermanland, we can see that there were relatively high numbers of clergy, church assistants, physicians and surgeons, but the county was also densely populated, had high infant mortality and a high rate of children being choked to death. The illegitimacy rate, however, was also high. Vaccination was least practised in the second most populated county, Göteborg och Bohus, which had the second lowest rates of clergy and church assistants. Infant mortality was relatively high, and there were fewer physicians and surgeons. Children choked to death and deaths from unknown disease placed Göteborg och Bohus among the most affected counties. By comparing the two extreme counties, it seems as though the number of clergy and church assistants was the only variable that shows an association with vaccination rates. A correlation test was performed to find the levels of significance for each variable. The correlated coefficient was in all cases vaccination rates.

It is only the number of clergy and church assistants per 100,000 inhabitants that correlate with vaccination rates in the Swedish counties. This indicates that it was organizational and not demographic or behavioural variables that were most influential in promoting obedience to the vaccination law. Behavioural variables indicating insufficient child care did not show a significant correlation with the practice of vaccination in Sweden between 1816 and 1820 .

Cultural variables certainly influenced mortality, including smallpox mortality. The success of vaccination, however, had more to do with organizational factors. Sweden had few physicians in the early nineteenth century, so preventive measures had to rely on a structure that had been set up to serve the whole society in earthly and heavenly matters: the parish meetings and the church. Each parish in Sweden had to appoint a responsible person to see that there was always a practising vaccinator. If there were families who did not want to have their children vaccinated, the problem was discussed at the parish meeting, and the clergyman read out all the names of unvaccinated children in the church.

\footnotetext{
${ }^{99}$ The children were claimed to have been accidentally choked to death during sleep in the bed of their mother or the woman who breast-fed them. K G Odén, Statistisk undersökning rörande våldsamma dödsfall $i$ Sverige. I, Stockholm, P A Norstedt \& Söner, 1875, pp. xx-xxi; E Nyström, 'The development of cause-of-death classification
}

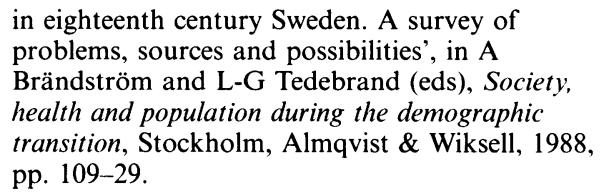
problems, sources and possibilities', in A Brändström and L-G Tedebrand (eds), Society, health and population during the demographic transition, Stockholm, Almqvist \& Wiksell, 1988, pp. 109-29. 


\section{The Organization of Smallpox Vaccination in Sweden}

Table 4

Correlation coefficients and p-values for demographic, organizational and behavioural variables compared to vaccination in 24 Swedish counties 1816-1820

\begin{tabular}{lcc}
\hline Variable & Correlation & p-value \\
\hline Inhabitants per square mile & 0.0337 & 0.786 \\
Clergy & $\mathbf{0 . 5 4 5 4 ^ { * }}$ & $\mathbf{0 . 0 0 6}$ \\
Church assistants & $\mathbf{0 . 4 9 8 7}$ & $\mathbf{0 . 0 1 3}$ \\
Physicians and surgeons & 0.0493 & 0.819 \\
Infant mortality rate & -0.2638 & 0.213 \\
Children choked to death & 0.2525 & 0.234 \\
Illegitimate children & 0.1855 & 0.385 \\
Deaths from unknown disease & -0.0595 & 0.782 \\
\hline
\end{tabular}

* numbers printed in bold are statistically significant.

Sources: Population records and mortality records for Sweden 1816-1820, Research Archive, Umeå University. C af Forsell, Statistik öfver Sverige. Grundad på offentliga handlingar. Facsimile 1833, 2nd ed., Stockholm, Rediviva, 1978.

During the eighteenth and nineteenth centuries, the Swedish church organization covered the whole country. Moreover, it was closely linked to the state. The clergy should serve the Lord, the King, and the people. Before vaccination, the clergy had taken part in important projects other than traditional church activities: for instance, during the seventeenth century they had been involved in teaching their parishioners to read. The national authorities considered the skill of reading to be very important for the state's efforts to educate and inform the public. Included in the church books were the catechism records, where the levels of literacy of adults and most children were noted. Around 1750 almost all Swedish adults were able to read, a very high rate compared with other European countries. ${ }^{100}$ The most common publications were religious texts, but during the eighteenth century information about health care and disease prevention appeared in popular almanacs. Dr Rosén von Rosenstein wrote a series of articles, including one on inoculation..$^{101}$

The clergy also held the key position in another administrative organization, which was unique to Sweden during the eighteenth century. In 1749 the Table Commission (Tabellverket) was established. In a strategy which paralleled that of vaccination, the clergy were obliged to send in annual tables with detailed information about births, deaths and marriages for each parish. The data was then compiled in

${ }^{100} \mathrm{E}$ Johansson, The history of literacy in Sweden in comparison with some other countries, Educational reports 12, Umeå University, 1977, pp. 34-6; U Högberg, Svagårens barn. Ur folkhälsans historia, Stockholm, Liber, pp. 19-23.
${ }^{101}$ B Vahlqvist, 'Nils Rosén von Rosenstein and his textbook on pediatrics', in B Vahlqvist and A Wallgren (eds), Diseases of children and their remedies, Acta Paediatrica, suppl. 156, Stockholm, 1964, pp. 27-69; Larsson, op. cit., note 33 above, pp. 49-50; Sköld, op. cit., note 21 above, pp. 255-8. 


\section{Peter Sköld}

Stockholm, and gave the state a great opportunity to survey the movements of population. ${ }^{102}$

The most important result of the discussion concerning public health during the eighteenth and early nineteenth centuries was that the state was declared responsible for this matter, and was expected to initiate measures for preventing diseases, curing the sick, and keeping the people as healthy as possible. ${ }^{103}$ This responsibility was shared with the clergy. They knew all their parishioners personally, and had every reason to help them. The changing ways in which the clergy themselves understood their work seems to verify the statements of Söderberg: high vaccination rates represented a break with fatalism and strong religious prejudices. The early nineteenth-century clergy were ready to fulfil the new ideals of the time. They could no longer rely simply on God's will and help; it was time for hard work, enlightened teaching and moral improvement, all with the same purpose: to create a stronger, wealthier and healthier country. ${ }^{104}$ People knew that susceptible persons increased the risk of an epidemic, which would threaten infants who had not yet been vaccinated. Hence, vaccination was made an duty for each individual (compulsory in 1816), organized and controlled by local government and the churches at local level.

Although vaccination alone cannot be credited with the rapid decline of smallpox in Sweden, it was definitely the single most important factor. Overall mortality fell sharply from around 1810 when the whole organization of public health was expanded and improved.

Jack Hopkins describes the eradication of smallpox in the twentieth century as successful because of "vertical organization", meaning that it was centrally-directed and single-purposed. ${ }^{105}$ The same model was used in nineteenth-century Sweden. By contrast, today the WHO can now combine different measures in the same health campaign.

A problem during the eradication campaign of the 1970s was the lack of enough suitably qualified doctors. Therefore, the importance of co-operation with local governments, church leaders and teachers increased. The strategy was to make full use of human resources; physicians encouraged contacts at local level, who could gain the confidence of the public. ${ }^{106}$ Nineteenth-century Sweden was in a similar position. County governors and cathedral chapters were instructed to participate in the organization of vaccination. They were necessary links to personnel at the local level. The cathedral chapters played an important part during the period before the

\footnotetext{
${ }^{102} \mathrm{E}$ Arosenius, 'The history and organization of Swedish official statistics', in J Koren (ed.), The history of statistics: their development and progress in many countries, lst ed. 1918, New York, Burt Franklin, 1970, pp. 535-69.

${ }^{103} \mathrm{R}$ Qvarsell, Vårdens idéhistoria, Stockholm, Carlssons, 1991, p. 160.

${ }^{104}$ E Johansson, 'Prästerna i övre Norrlands kustbygd-Blad ur ett forskningsprojekt', in S Henrysson (ed.), Samer, präster och skolmästare.
}

Ett kulturellt perspektiv på samernas och Övre Norrlands historia, Rapport nr 23, Umeå,

Centrum för arktisk forskning, 1993, pp. 97-122, 118-19.

${ }^{105}$ Hopkins, op. cit., note 56 above, pp. 51-2.

${ }^{106} \mathrm{D}$ Henderson, 'An end-and a beginning', World Health, Feb.-March 1975: 12-17, on p. 17;

D J Sencer, 'Lessons for the future', ibid., pp. 18-21; Hopkins, op. cit. note 56 above, pp. 62-3; Fenner, et al., op. cit., note 67 above, p. 515. 


\section{The Organization of Smallpox Vaccination in Sweden}

first Vaccination Law of 1816 by instructing the clergy to promote vaccination in their churches; while county governors were to control and administer vaccination in the district. Together with the cathedral chapters, they were responsible for ensuring that every parish had a vaccinator and a supervisor. After 1816, they were also responsible for enforcing the law, and the reports from the district physicians were sent to them first so they could immediately deal with potential problems. ${ }^{107}$ However, there were insufficient physicians and the question was not if, but how, the lay people should be used.

So that all human and organizational resources were involved in an efficient way, the existing church organization was called into service. ${ }^{108}$ The clergy combined the interests of both church and the state, since they chaired the parish meetings. They were also involved in health care, with instructions to inform the district physician and the governor about the occurrence of infectious diseases. Moreover, they kept the parish death registers and theoretically noted all causes of death. ${ }^{109}$ The clergy had the responsibility to disseminate information about and to encourage vaccination in their parishes. They were not given as active a part as vaccinators, but their position in the parish was so central that in practice their role was one of the most important. ${ }^{110}$ As chairs of parish meetings, it was the responsibility of the clergy to ensure that the vaccinator did a good job and that parents had their children vaccinated, as well as to raise money in church to guarantee the financing of this practice. ${ }^{11}$

Sweden's early vaccination organization was efficient by comparison with that of other European countries. ${ }^{112}$ Government and medical authorities were immediately positive, and this was important. By involving the church, the Medical Board used an existing organization. The clergymen represented both

${ }^{107}$ Kongl. Maj:ts Nådiga Circulaire Til Samtelige Landshöfdingarne och Consistorierne, om Hvad iakttagas bör $i$ afseende på Smittosamma Sjukdomar. Gifvet Haga Slott den 25 Augusti 1813, Stockholm, 1813. Kongl. Maj: ts nådiga reglemente för vaccinationen $i$ riket. Gifwet Stockholms slott den 6 mars 1816, Stockholm, 1816. See also Norrman, op. cit., note 1 above, pp. 105-6. 'Kongl. Maj:ts nådiga kungörelse om ändringar och tillägg uti en del Medicinal-författningar, till beredande af en förbättrad hälsowård i Landsorterne. Gifwen Stockholms Slott den 27 Februarii 1828', in Swensk Författnings Samling, 1828, no. 77, pp. 1523-7.

${ }^{108}$ Towns did not follow the parish system, which forced the authorities to find alternative plans. By 1805 Stockholm had already had its first instructions about vaccination. ÖfwerStåthållare-Embetets Kungörelse, om Det af Kongl. Maj:t, jemte widtagne anstalter til Vaccinationens befrämjande här i Staden, tillika utsatte answar för dem, som underlàta att anmäla ypppad naturlig Koppsmitta. Gifwen Stockholm den 11 April 1805, Stockholm, 1805.

\footnotetext{
${ }^{109}$ Gustafsson, op. cit. note 3 above, pp. 246-47.

${ }^{110}$ Several clergy were also actively practising vaccination, especially at the beginning of the organizational process. Anders Langevall in Dannemora, for example, in 1804 vaccinated many children and promoted the method in the church. When a two-year-old boy died and eight others were infected in 1807 , vaccination was generally requested and Langevall knew that he could not vaccinate everyone himself. Therefore he trained two other clergymen and two church assistants. Vaccination report from Rev. Anders Langevall, Dannemora, 17 January 1808, Vaccination reports 1808 (E4:4), Medicinalstyrelsens äldre arkiv, Riksarkivet.

${ }^{111}$ W Beskow, Kyrkobokföringen och dermed sammanhängande stadganden. Stockholm, Ivar Hæggströms Tryckeri, 1894, pp. 121-3; Norrman, op. cit. note 1 above, pp. 106-7.

${ }^{112}$ England, France, Prussia, and most other European countries had great problems in organizing and promoting vaccination during the first half of the nineteenth century. Sköld, op. cit., note 26 above, pp. 363-7 and pp. 383-6.
} 


\section{Peter Sköld}

the state and the church, which made them more likely to be listened to in the parishes. A vaccine supervisor in every parish guaranteed that a vaccinator was appointed and that he sent in annual reports. The local clergy also kept records of vaccinated and unvaccinated persons. This created a unique national record of vaccination, dating from 1804 . We have also seen that the factors that were stressed in promoting the world eradication campaign of smallpox in the 1960s and 1970s had already occurred in early nineteenth-century Sweden. Moreover, they were successfully employed. ${ }^{113}$

${ }^{113}$ Fenner, et al., op. cit. note 67 above, p. 515. Leavitt states that the fight against smallpox in the nineteenth century taught Milwaukee public health officials a lot about controlling public health problems. J W Leavitt, The healthiest city: Milwaukee and the politics of health reform, Princeton University Press, 1982, pp. 120-1. 